\section{AZ AGILITÁS SZEREPE A BIZTOSÍTÁSI SZEKTORBAN}

Hernády Balázs (Posta Biztositó), hernady.balazs@mpb.hu - Vanczák GergelyPál(Posta Biztositó), vanczak.gergely@mpb.hu

\section{ÖSSZEFOGLALÓ}

A világ átalakulóban van, és ehhez új kihívások és követelmények is tartoznak. Az egyik ilyen követelmény az agilis müködésre vonatkozik, amely az elmúlt években egyre több vállalatnál került a figyelem középpontjába, egy teljesen új szemléletmódot beemelve a menedzsmentek mindennapjaiba. Kutatásunkban azt vizsgáljuk, mi is az agilitás, milyen értelmezései, rétegei vannak, és milyenné kell nekünk személyesen és szervezeti szinten válnunk, ha agilisak szeretnénk lenni. Nem gondoljuk, hogy az agilitásra valaha is születhet olyan leírás, amelyet követve egy szervezet könnyen és gyorsan agilissá válhat. Ez egy folyamat, a melyet mindenkinek magának kell végigjárnia. Azonban azt gondoljuk, hogy a biztosítási szektor előtt álló kihívások miatt a szektor résztvevőinek agilissá kell válniuk, amihez érdemes ismerni az agilitás témaköreit és alapelveit. Ezeket igyekszünk bemutatni e cikkben. Minden nagyobb szervezetnek ajánljuk, hogy ezeket az új megközelítéseket elöször kis csapatban próbálják ki, saját jó megoldásaikat kikísérletezve, majd utána ennek tanulságait levonva menjenek tovább az agilitás útján, és változtassák meg a teljes szervezet működését.

\section{SUMMARY}

The world is changing, and there are new challenges and requirements for organizations. One requirement is an agile operation, which has come to the forefront of attention in more and more companies in recent years, incorporating a whole new approach into the everyday lives of management. In our research, we examine what agility is, what its interpretations and layers are, and what we need to become agile at a personal and at the organizational level. We don't think there will ever be a description of "how can your organization transform into agile easily and quickly". It is a process that everyone must go through on their own. However, we believe that due to the challenges facing the insurance sector, the participants in the sector need to become agile, for which it is worth knowing the topics and principles of agility. We will try to present these in this article. We recommend that all larger organizations first try these new approaches in a small team experimenting with their own good solutions, and then, drawing lessons from this, continue on the path of agility and change the way the entire organization works.
Kulcsszavak: agilitás, vezetés, projektmenedzsment, szervezetfejlesztés, ökoszisztémák Keywords: agility, leadership, organization, project management, organizational development, ecosystems

\section{JEL: M100, O310}

DOI: $10.18530 /$ BK.2020.3-4.50

http://dx.doi.org/10.18530/BK.2020.3-4.50

\section{Bevezetés}

A világ átalakulóban van: digitalizáció, változó vásárlási preferenciák, a perszonalizáció igénye, környezeti változások. Az új világhoz pedig új szabályok is tartoznak. Azok a vállalatok maradhatnak életben, amelyek alkalmazkodni tudnak az új környezethez. Bár látszólag a nagy és öreg vállalatok számára ez lehetetlen, már számos olyan példa van, ahol egy érett, tradicionális vállalat is képes volt a megújulásra. Például a Saab, amely képes a világ legjobb vadászrepülőit gyártani, ráadásul szinte a legolcsóbban, vagy a Barclays Bank, amely szintén sikeresen vette az akadályt.

A kulcs a változáshoz és az új szabályokhoz nem más, mint az agilitás. Az agilitás, amely egy teljesen új látásmódot hozott a menedzsmentbe abból a szempontból, hogy milyen elvek, értékek és metódusok szerint működik egy vállalat. Bár a technológia hozta el ezt az új világot, a hatékony válasz véleményünk szerint mégis az agilis szemléletben rejtőzik. A technológia hozzáférhető mindenki számára, a pénz és a tőke már nem csak a kiváltságosok számára elérhető. (Elég csak a hatalmas kockázati tőkealapokra gondolni.)

Ami megkülönbözteti a sikeres vállalatokat a sikertelenektől, az az, hogy hogyan tudnak ezekből a változásokból lehetőségeket alkotni, majd azokat kihasználni. Ehhez nyitottságra, kreativitásra, lelkesedésre és gyorsaságra van szükség.

Az agilitás roppant népszerű fogalommá vált. A vállalatvezetők, a tanácsadók és a kutatók mind azt mondják, hogy mindenkinek agilissá kell válnia minél gyorsabban. De mit is jelent ez az agilitás? Új projektmenedzsment eszközöket? Új szervezési metódusokat? Új hozzáállást és gondolkodásmódot? Milyen módon hat ez a biztosítási szektor vállalataira? Többek közt ezekre a kérdésekre keressük a választ ebben a cikkben.

\section{Változó kihívások a biztosítási szektorban}

A Capgemini és Efma $(2019,2020)$ és egyéb tanácsadótársaságok jelentéseiből láthatjuk, hogy a biztosítási szektort számos környezeti változás befolyásolja, és ezek a trendek az elörejelzések szerint egyre gyorsabban fejtik ki hatásaikat. Ha környezeti elemzést végzünk, akkor azt látjuk, hogy annak mindegyik szegmensében számos kihívást találunk 
A legmeghatározóbbak ezek közül azonban a természeti környezet és a technológia változásai, amelyek nagy hatással vannak a társadalmi környezetre is.

A természeti környezet nagymértékủ változása mára meghatározó, mainstream téma lett a közbeszédben. Az éghajlatváltozás és a globális felmelegedés következményei nehezen megjósolhatók, de az biztos, hogy igen nagy kihívások elé állítják társadalmunkat, mind kollektív, mind személyes szinten. Az előrejelzések szerint a szélsőséges időjárási jelenségek világszerte erősödni fognak. Így Magyarországon is több viharra, árvízre, kánikulára és szárazságra számíthatunk. (Nemzeti Fejlesztési Minisztérium, 2017) Ezek vagy a vagyontárgyakban tehetnek nagy károkat, vagy az egészségünkre lehetnek káros hatással (például hőhullámok hatására az időskori halandósági ráta növekedése várható). Mindkét esetre fel kell készülniük a biztosítóknak. Az ezen változásokhoz való alkalmazkodást nagyban segítik az új technológiák, amelyek bevezetése és hatékony használata újabb nagy kihívás számukra.

A technológiai változások igen lassítva érik el a magyar (és részben az uniós) piacot, aminek meglátásunk szerint két fő oka van, az egyik, hogy a biztosítási piac igen erősen szabályozott mind az Unióban (Basel III., Szolvencia II., GDPR), mind pedig Magyarországon, összehasonlítva a tengerentúli piacokkal vagy az ázsiai térséggel. Az egyre szigorúbb és terjedelmesebb biztosításüzleti szabályokra (amelyek a papírmentes folyamatok kialakítását önmagában is nehezítik) az elmúlt időszakban újabb szabályozók rakódtak pénzmosás, adatvédelem stb. területén. A másik ok, hogy mivel Magyarország egy kis piac, a különböző réspiacokra szánt termékekből származó bevételek nem fedezik a befektetések megtérülését. Mindezek ellenére a technológiai fejlődés utol fogja érni hazánkat is, ugyanis a Big Tech cégek ${ }^{1}$ (melyek jelen vannak hazánkban is) fenyegetést jelentenek a globális és a hazai biztosítási szektorra is.

A jelenlegi koronavírus-járvány következtében beköszönő változások tovább gyorsították a technológiai fejlődés sebességét. A Capgemini (2020) által készített kutatásból kiderül, hogy a koronavírus „rákényszerítette” minden generációra, hogy megtanulják használni a digitális és online eszközöket napi szinten, mind vásárlásra, mind információszerzésre. Az X generáció (1980 előtt születettek) 30 százaléka 2018-ban, 43 százaléka 2019-ben és 64 százaléka 2020-ban nyilatkozott úgy, hogy már rendszeresen használja az online vásárlás lehetőségét (appok és weblapok), azaz két év alatt duplázódott ezen felhasználók aránya. Ezenkívül a járványügyi szigorítások következtében az offline értékesítési lehetőségek (ügynöki hálózat) igen jelentős mértékben korlátozódtak.

Ezek jól mutatják, hogy ha a biztosítók nem tudják jelentősen növelni az online értékesítésüket, akkor lemaradhatnak a versenyben. Ma már a potenciális ügyfelek elvárásai igen magasak. A biztosítás megkötésekor is szeretnék átélni azt a vásárlási élményt, amelyet más szektorokban megszoktak, és mindent néhány kattintással elérni. Ezek kifejlesztését olyan eszközök segíthetik, mint a prediktív analitikák, a különböző AI és deep learning technológiák, adatbányászat stb.
Habár a szektor szereplői számára egyértelmű, hogy nagyon fontos lenne befektetni ezen technológiák és vállalati képességek kifejlesztésébe, mégis azt látjuk, hogy a kellő mértékű beruházások még nem indultak el, főleg azért, mert a biztosítók körében túl nagy a bizonytalanság ezen beruházások megtérülését illetően. (Bender et. al., 2020) A következő fejezetben szeretnénk bemutatni az egyik legnagyobb kihívást, amely az új üzleti modellre való átállás szükségessége.

\section{2. Ökoszisztémák és platformok}

Mint láthattuk, a piaci versenyben való lépéstartáshoz szükség van többek között a legújabb gazdaságszervező eszközök implementálására is. Ilyen eszközök lehetnek a mostanság meghatározó ökoszisztémák, mely a „kapcsolódó termékek és szolgáltatások összessége, amelyet egyetlen szervezö közremüködésével juttatunk el az ügyfelekhez, integrálva a többi résztvevőt egy zökkenömentes élménybe”. (Talanx Best Practice Lab, 2020)

Megjelent a platform business (platformra épülö üzleti modell), amely a pipeline business (hagyományos lineáris értékesítési csatornára épülő modell) helyébe léphet. Utóbbi szerint „az ipari korszak sikeres vállalatait úgy tervezték, hogy megoldást hozzanak létre egy ügyfél számára, csökkentsék a gyártás és forgalmazás költségeit, és marketing üzeneteket vezessenek az értékesitésre: más szóval, bármilyen áron elérjék a méretgazdaságosságot”. Ezzel szemben a platform gondolkodás azt mondja, hogy „a platformok összekapcsolják és képessé teszik az entitásokat referencia-ökoszisztémájukban egy olyan térben, amelyet kifejezetten interakcióra, összekapcsoltságra és értékcserére fejlesztettek ki - a hálózat méretének növekedésével egyre vonzóbbá és értékesebbé válnak a résztvevök számára”. (Talanx Best Practice Lab, 2020) Azaz a platform lényegében egy újfajta stratégiai irányvonalat jelent, amelynek mentén az entitások (gyártók és ügyfelek) egy ökoszisztémát, közösséget hoznak létre, amely alapjaiban alakítja át az értékteremtő folyamatokat. A pipeline business a lineáris értékláncokban, az ellátási láncok irányításának erejében, a kínálati oldali méretgazdaságosságban, a tárgyi eszközök és a tőke értékcsökkenésében, a csökkenő hozamban, a szervezeti növekedésben és a szabványfolyamatokban, rutinmegoldásokban és határokban látja a gazdasági fejlődés és a piaci térnyerés lehetőségét. Ezzel szemben a platform business a nemlineáris információvezérelt ökoszisztémákra, az ökoszisztémák tőkeáttételének erejére, a keresleti oldali méretgazdaságosságra, a digitális eszközökre és az innovációs tőkére, a hálózati hatásokra, az aszimmetriák és a hálózatok által vezetett növekedésre, valamint a komplex fejlesztésekre és önszerveződő integrációra építve kíván értéket teremteni a fogyasztók számára. (Talanx Best Practice Lab, 2020) Egy ökoszisztéma akkor lehet sikeres, ha minél több szereplöje van, minél több fogyasztót ér el. Olyan platformokat kell kialakítani, melyek a társadalom egy már létező nagyobb szegmensét vagy egy még nem felismert, de elöre láthatólag nagy igénnyel bíró (piaci) rést céloznak meg, amelyek a lehető legtöbb potenciális felhasználóval bírnak majd. Előbbire lehet példa a bringás közösség vagy az online vásárlók közössége. Számukra kínálnak a legkülönfélébb szolgáltatók egy platformon keresztül különböző szolgáltatásokat, amelyek egyrészről teljesebbé tehetik az ügyfélélményt, másrészről 
minden szolgáltató ügyfélköre lehetséges új ügyfelet jelent az ugyanabban az ökoszisztémában részt vevő másik szereplőnek, ezzel közösen erősítve egymást. Bár egy ökoszisztéma alapja sok minden lehet (státusz, termék stb.), úgy gondoljuk, hogy egy biztosítási termék viszont soha nem lehet ennek alapja, hiszen biztosítást csak egy nagyobb kár terhének elkerülése érdekében köt az ember. Bár ezt szükségszerüen sokan kötik (kgfb, lakás- és utasbiztosítás), nem lehet társadalmi rétegekre vagy a társadalom különböző szegmenseire specifikusan árusítani, illetve meglehetősen nehéz mindezekhez kapcsolódni és kapcsolt termékeket társítani. Ugyanakkor, ha megfordítjuk a gondolatmenetet, és egy már létező közösséget kutatunk fel, számukra létre lehet hozni egy egyedi biztositási terméket, amelyet az ő igényeik szerint alakítanak ki. A közösség tagjaiban nincs az a kényszerérzés, hogy kötelező megvenni ezt a biztosítást, viszont szabadon dönthetnek arról, hogy azt, amit csinálnak, biztonságban tegyék (pl. biciklizéshez speciális baleset-, vagyon- vagy felelősségbiztosítás).

\section{Ahhoz, hogy ezen változásokhoz sikeresen tudjon egy vállalat alkalmazkodni, szükségszerü, hogy új szemlélettel, vezetési és munkaszervezési módszerekkel szerelkezzen fel.}

Összességében megállapíthatjuk, hogy amennyiben az agilitás egy újfajta, környezetéhez gyorsan alkalmazkodó gondolkodásmódot (is) jelent, mind egyéni, mind pedig szervezeti szinten, üzleti modellünk agilissá tételének prosperáló módja lehet, ha ökoszisztémákban kezdünk el gondolkodni, keressük a kapcsolódási pontokat közösségekkel és más vállalatokkal, és ezeknek következtében tevékenységünkkel csatlakozunk egy - már meglévő vagy még kialakulófélben lévő - platformhoz.

Láthatjuk tehát, hogy a mai kor hagyományos, régebb óta működő vállalatai számos kihívás és változás előtt állnak. Új módon kell gondolkodniuk saját magukról és a környezetükről. Ahhoz, hogy ezen változásokhoz sikeresen tudjon egy vállalat alkalmazkodni, szükségszerü, hogy új szemlélettel, vezetési és munkaszervezési módszerekkel szerelkezzen fel. Úgy gondoljuk, az agilitás lehet a kulcs, amelynek segítségével egy vállalat képes lesz folyamatosan alkalmazkodni az új helyzetekhez.

\section{Az agilitás}

Az agilitás fogalmának keretrendszere nem kiforrott, párhuzamosan több jelentés és kifejezés él a köztudatban. Sokaknak olyan hívószavak jutnak az eszükbe, mint például tanulási képesség, rugalmasság vagy alkalmazkodóképesség a gyorsan változó világhoz. Akik járatosabbak a menedzsment valamely formájában, akár a Scrum, Lean vagy OKR módszertanokkal is kapcsolatba kerülhettek. Megint másoknak olyan startupok jutnak eszükbe, ahol kis csapatok decentralizáltan dolgoznak magas hozzáadott értékủ termékeken. A piacon jelenleg elfogadott terminológia alapján mindegyik állítás igaz, hiszen maga az agilitás mindezt magába foglalja. Gyakorlatilag gyűjtőfogalommá vált.
A fogalom értelmezésének diverzitása önmagában nem jelent problémát, hiszen alapvetően hasonló elemek jelennek meg a fent felsorolt válaszokban. Mivel azonban ennyire divatos kifejezés a menedzsmentben, sokszor olyan gyakorlatokra is használják, amelyek nem kapcsolódnak szorosan az agilitáshoz, vagy olyan eszközöket, metodológiákat értenek alatta, amelyek nem újak, csupán a megnevezésük kap új formát. A fogalom kannibalizálódása oda vezetett, hogy az agilitás önmagában definiálatlan, de trendi hívószóvá vált.

Szemléletes összefoglaló az úgynevezett „agile onion” (magyarul: agilis hagyma), amely bemutatja, milyen rétegei is vannak az agilitásnak. Mi halmazokként tekintünk az 1. ábrára.

1. ábra: Az agilitás rétegei

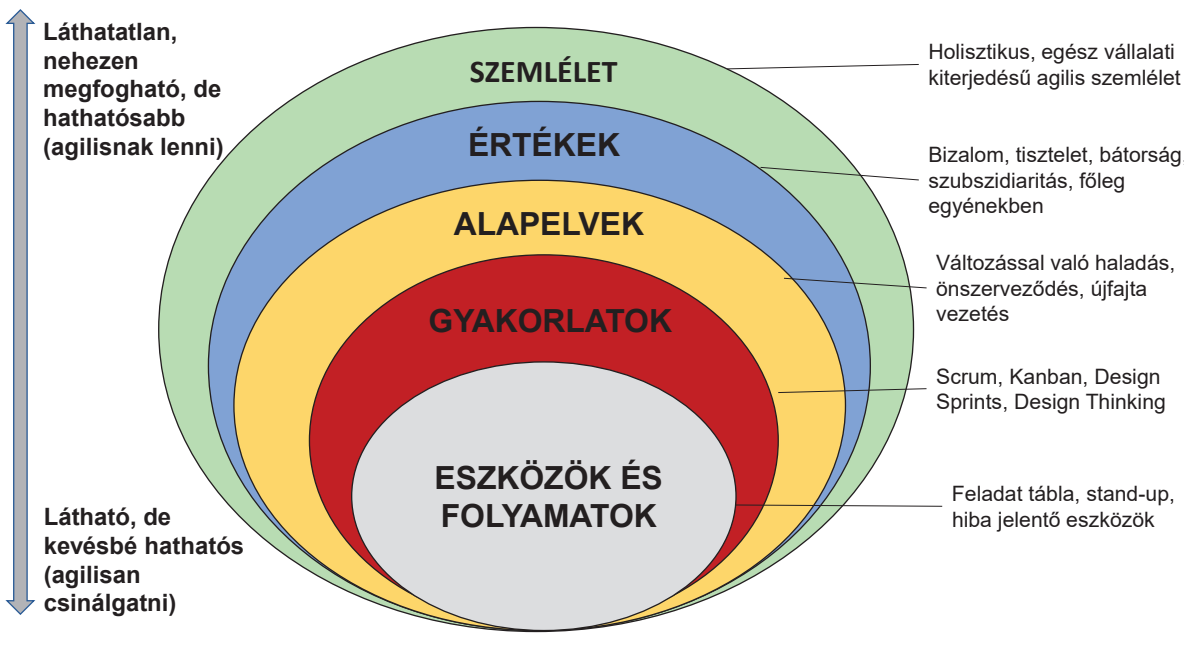

Forrás: saját szerkesztés Powers, 2017 ötlete alapján

Azt gondoljuk, hogy annál nagyobb a változás, és annál nagyobb mértékben sikerül adaptálni az agilitást, minél nagyobb halmazba sikerül a vállalatnak kerülnie.

Míg a két alsó szintet a felsővezetéstől érkező döntés, utasítás viszonylag egyszerüen bevezetheti, addig az alapelvek elfogadásához és az értékek felvételéhez egy szervezetben már strukturális és kulturális változások is szükségesek. Ahhoz pedig, hogy egy vállalat munkavállalói szinten és csapatként is agilissá váljon, már tanuló szervezetté is kell válnia, amelynek elméleti alapjait már 30 éve letették. (Senge, 1990)

Ezen rétegek kölcsönös hatással vannak egymásra, ugyanis például, ha nincsenek meg a megfelelő értékek egy vállalatban, akkor ez a szervezet csak nagyon hosszú idő alatt tudja elsajátítani az agilis szemléletet. Vagy amíg klasszikus struktúrát és erősen standardizált folyamatokat követ, addig nem nevezhetünk egy szervezetet strukturális szempontból agilisnak. Tehát ahhoz, hogy kialakuljon az agilis szemlélet, számos tudatos változtatásra 
van szükség. Egy-egy agilis eszköz vagy folyamat bevezetése segítheti az agilis szemlélet erősödését, azonban ettől még nem lesz törvényszerűen agilis egy csoport vagy szervezet. Véleményünk szerint az agilis szemlélet eléréséhez stratégiai megközelítés szükséges, amely egy sor tevékenységet magába foglal, gyakorlatilag a hagyma összes rétegét felölelve.

Egy-egy agilis eszköz vagy folyamat bevezetése segítheti az agilis szemlélet erősödését, azonban ettől még nem lesz törvényszerüen agilis egy csoport vagy szervezet.

Ugyanakkor az is lehetséges, hogy egy szervezet és annak tagjai rendelkeznek agilis szemlélettel és értékekkel, csak a „tradicionális” szervezési és munkavégzési szabályok és folyamatok miatt nem tudják kiaknázni az agilitásukból származó összes előnyt. Ehhez szükséges olyan agilis szervezési eszközöket és metodológiákat alkalmazni, amelyek segítenek teljes mértékben kiaknázni a szervezetben lévő potenciált.

Mi tehát a következő definíció szerint tekintünk az agilitásra: Az agilitás olyan eszköz- és keretrendszer, amelynek segítségével egyének és szervezetek képesek gyorsan és rugalmasan alkalmazkodni a változásokhoz.

A következőkben részletesen megvizsgáljuk az agilitást és annak egyes rétegeit/értelmezéseit a szemlélettől a gyakorlatokig. Holisztikus képpel indulunk, és haladunk a mélyebb rétegekig, hogy megértsük, mi is az agilitás. A következő fejezetben szeretnénk körüljárni az agilis szervezetek fö ismérveit.

\section{Agilis szemlélet}

Több definíciót is találhatunk arra, mit jelent az agilis szemléletmód egy vállalatban. (Denning, 2018, Powers, 2017) Két elem azonban mindenhol azonosítható: azok a vállalatok, amelyek sikeresen adaptálták az agilis szemléletet, a megszokottól eltérő módon szorosabb kapcsolatot tartanak fenn ügyfeleikkel, más módon irányítják a munkavállalóikat, egyszóval másfajta hozzáállásuk van a fejlődéshez és a tanuláshoz, mint azon cégeknek, amelyek nem tekinthetők agilisnak.

\subsection{Tulajdonosi vagy ügyfélérték-maximalizás?}

Az agilis szemlélet egyik „törvénye” (Denning, 2018) szerint máshogy kell interakcióba lépni az ügyfelekkel. A szerző hivatkozik Peter Druckerre, aki azt állította, hogy egyetlen érvényes definíciója van az üzleti célnak: ügyfelet alkotni (create a customer). Drucker szerint hosszú távon a legfontosabb, hogy a vállalat elkötelezetten dolgozzon azon, hogy magas értéket állítson elő az ügyfeleknek, és e célja elé semmi mást ne rendeljen. (Drucker, 1954) Azonban az elmúlt évtizedekben, főleg a nagy részvénytársaságok esetében azt látjuk, hogy a vállalatok többsége nem így cselekedett. A tradicionális üzleti „közmegegyezés” szerint az üzleti vállalkozás legfőbb célja, hogy profitot termeljen a tulajdonosoknak („maximize shareholder value”). Ezt legjobban az Egyesült Államokban tevékenykedő nyílt részvénytársaságok példája mutatja, ahol rengeteg döntés csak azért született, hogy a pillanatnyi részvényárfolyamok emelkedjenek. (Természetesen nem állítjuk azt, hogy tradicionálisan kialakított szervezetek szükségszerüen fontosabbnak tartják a tulajdonosi érdeket az ügyfélérdeknél, pusztán azt mondjuk, hogy agilis szemléletủ vállalatként az ügyfél az első.)

Ezzel szemben az agilis vállalatok az ügyfélnek adott értékre koncentrálnak, és hajlandók hosszú távon megtérülő befektetésekbe bocsátkozni csak ezen cél elérése érdekében. Jól tetten érhető ez abban is, hogy az agilis vállalatok a kibocsátás és produktivitás (output) helyett a hasznos végeredményre (outcome) és az ügyfél-elégedettségre fókuszálnak. Ez a szemléletváltás a vállalati kultúrában Denning szerint hasonló ahhoz, mint amikor a középkorban Kopernikusz felfedezte, hogy nem a Föld körül kering a Nap, hanem fordítva. A cégeknek fel kell ismerniük, hogy nem a fogyasztók vannak az ő profitjukért, hanem ők a fogyasztók igényeinek minél jobb kielégítéséért. (Denning, 2018)

\section{Az agilis vállalatok az ügyfélnek adott értékre koncentrálnak, és hajlandók hosszú távon megtérülő befektetésekbe bocsát-} kozni csak ezen cél elérése érdekében.

Az agilis szemléletủ vállalkozások komplex problémákat oldanak meg, úgynevezett komplexitás hiedelemmel rendelkeznek. (Powers, 2017) A komplex problémák egyik legfontosabb tulajdonsága, hogy a végeredmény a problémamegoldási folyamat elején nem kiszámítható (ezért a vízesésalapú termékfejlesztési metódus nem vezet eredményre). Azok a szervezetek, amelyek a komplexitási hiedelmen keresztül teszik magukévá az agilitást, általában alárendelik magukat az ügyfelek interakcióinak, pontosan azért, mert tudják, hogy csak így találhatják meg az elvárt terméket, szolgáltatást vagy folyamatot, azaz a végső megoldását a problémának. Nagyon fontos továbbá, hogy a céges kultúrában növeljék a transzparenciát, tehát minden résztvevőnek világos legyen, hogy egyes döntések ki által és miért születtek meg - ezt a viselkedéskultúrát alkalmazzák az agilis módszertanok is.

\subsection{A tanuló szervezet}

Az agilis szemléletű vállalkozásoknak tulajdonságuk, hogy az egész cég elkötelezett a folyamatos tanulás és tanítás mellett. (Nemcsak a belső érintettekkel, hanem a külsőkkel szemben is.) Például fontosnak tartják az ügyféledukációt. (Véleményünk szerint a pénzügyi szektorban ebben nagy lemaradás van.) Itt fontos megemlítenünk a tanuló szervezetet. A tanuló szervezet egy olyan hely, ahol az emberek ,folyamatosan kibontakoztatják képességeiket, beteljesitik valódi céljaikat, amelyek során támogatják a gondolkodás(módok) új fajtáit és új közös vágyakat valósitanak meg, tehát olyan szervezetek, amelyekben az emberek megtanulják, hogyan tanuljanak együtt." (Senge 1990 13. old). Azt gondoljuk, 
hogy ezen szemlélet elsajátítása nagyon fontos, szinte nélkülözhetetlen ahhoz, hogy egy szervezetre azt mondhassuk, hogy agilis szemlélettel rendelkezik. A tanuló szervezetek Senge által kifejtett öt alapelvének mindegyike nevezhető agilisnak. A második diszciplína például, hogy a szervezetet alkotó egyének személyes szinten is törekedjenek a kiválóságra. Itt el is jutottunk oda, mit jelent az agilitás egyéni szinten.

\subsection{Egyéni szintü agilis értékek}

A személyes szintü agilitás azt jelenti, hogy az egyének maguk is agilisak, képesek a folyamatos megújulásra és tanulásra, a változásokhoz való alkalmazkodásra. Fontos, hogy az egyéneknek lehetőségük és akaratuk is legyen új ötletek kezdeményezéséhez, megvitatásukhoz és az ebből kifejlődött projektek lelkes véghezviteléhez is. A proaktivitás nélkülözhetetlen eleme annak, hogy egy szervezet agilissá váljon. Az agilis személyek nyitottak, és belülről fakadó kíváncsiságot, érdeklődést mutatnak a tanulásra, az új tapasztalatok megszerzésére. Ezenkívül képesek elismerni, ha valamit nem tudnak, mert nem kell félniük ennek következményei miatt, ugyanis bizalmi, támogató légkörben dolgoznak.

Ezen személyek továbbá nem dogmatikus, hanem pragmatikus hozzáállással rendelkeznek. Mindez megmutatkozik a folyamatszervezésükben, a praktikáikban és az eszközeikben is. (Lásd az agilitás alsóbb szintjeiben.) A munka során képesek őszinte és konstruktív, akár egyet nem értő kritikai visszajelzést is adni egymásnak. Ezt segíti, hogy a szervezet tagjai a hibázásra és kudarcokra tanulási lehetőségként tekintenek. Nagyon fontos végül, hogy az agilis szemléletű szervezetben az egyének az innovációra és a megújulásra nem kockázatként, hanem a túlélés zálogaként tekintenek.

Láthatjuk, hogy az agilis szemléletnek mind összvállalati szinten, mind egyéni szinten meg kell valósulnia. Úgy véljük, a vezetők kiemelkedően fontos szereplők az agilitás szervezeti szintű megvalósításában és ezen értékrend meghonosításában, ezért majd egy későbbi fejezetben röviden megvizsgáljuk, milyen egy agilis vezető, illetve, hogy mit jelent az agilis szervezetvezetés az ismert menedzsmentfunkciók szempontjából. (Dobák - Antal, 2010)

\section{Agilis vezetési és szervezési értékek}

Az Agilis Manifesztó ${ }^{2}$ négy alapértéket tartalmaz, amely szoros összefüggésbe hozható a jól ismert menedzsmentfunkciókkal: személyes interakciók előnyben részesítése, (jól) működő szoftver, (erős) kollaboráció az ügyféllel, reakció a változásokra. Ezen elvek ugyan a szoftverfejlesztési iparágra vonatkoznak, de kiterjeszthetők más iparágakra is, ha némileg mögéjük nézünk. (Beck et al., 2001)

\subsection{Vezetés: személyes kapcsolatok}

A személyes interakciók előnyben részesítése a folyamatok, eszközök és a kötött szabályok helyett. Ez azt jelenti, hogy egy agilitásra törekvő szervezetben fontosabb az emberek között kialakuló bizalom és a szubszidiaritás elvének kialakítása és fenntartása, mint a kötöttség és a szabályozott folyamatok a hatékonyság növelésének érdekében. Ezen körülményeket véleményünk szerint nem lehet egy autokratikusan vezetett, erősen formalizált, centralizált döntéshozatallal rendelkező szervezetben vagy csoportban kialakítani.

Ezek felszámolása nagy váltás tud lenni egy tradicionális szervezet életében, és igen nagy bátorságot igénylő döntés a felsővezetők részéről. Ezt bizonyítja például, hogy számos kreatívabb szektorban vagy munkakörben is például azt fizetik meg, hogy egy munkavállaló hány órát tölt az irodában, és nem azt, hogy milyen feladatokat végzett el, és ezzel mekkora értéket teremtett, pedig a munka jellegéből adódóan ez utóbbiakat kellene figyelembe venni az agilitás növelésének érdekében. Nagyfokú bizalom szükséges ahhoz, hogy egy vezető szabad kezet adjon beosztottjának, ezért utalnánk vissza az előző fejezetben arra a részre, hogy agilis szemlélet nélkül nehéz megbízni az alkalmazottakban, az ö képességeikben és elköteleződésükben.

\subsection{Tervezés: „Müködő termék”}

Fontos érték a „működő szoftver az alapos dokumentáció helyett”, azaz általánosan lefordítva a működő termék vagy szolgáltatás. Egy cég akkor tud sikereket elérni, ha valóban megfelelő, az ügyfelek igényeire szabott terméket vagy szolgáltatást képes adni. Alapvetően az alapos dokumentációval se lenne probléma, azonban fontos megérteni, hogy ez nem lehet fókusz; a bürokratikus akadályokat minél jobban le kell bontani, hogy a termékfejlesztők vagy egyéb csapatok teljes figyelme az ügyfeleik (egy HR csapatnak is vannak ügyfelei: a munkatársak) igényeinek, vágyainak folyamatos magas színvonalon való kielégítését szolgálja, és a munkát ne jelentésekkel és adminisztratív eszközökkel igazolják, hanem ügyfeleik elégedettségével.

\subsection{Ellenőrzés: „Ügyfél-elégedettség”}

A harmadik fontos érték a kollaboráció az ügyfelekkel a (szerződéses) tárgyalások helyett. Ez az érték szintén majdnem minden szervezetre kiterjeszthető. Arra van szükség, hogy folyamatos kommunikációt és bizalmi kapcsolatot alakítsunk ki az ügyfeleinkkel, megbízóinkkal. Ez sokkal hatékonyabbá teszi az együttműködést, hiszen mindkét fél örül. Ez egy B2C („kiskereskedelmi”) piacon működő szervezet számára azt jelenti, hogy folyamatosan figyeli a visszajelzéseket az ügyfelektől, válaszol a kérdéseikre, egyéni igényeikre. 


\subsection{Szervezés: „Változásból versenyelőny”}

A negyedikérték, amely szerintünk a legfontosabb, hogy egy szervezet reagáljon a változásokra, ahelyett, hogy elöre rögzített terveket követne. Ez az érték feltételezi a többi három meglétét is, hiszen úgy tudunk csak gyorsan reagálni a változásokra, ha időben felismerjük ezeket, ehhez pedig folyamatos és jól müködő ügyfélkapcsolatra van szükségünk. Ahhoz, hogy reagálni tudjunk a változásokra, hatékony belső kommunikációra van szükségünk. A mai gyorsan változó világban nincs idő arra, hogy egy elöre pontosan elkészített éves tervet valósítsunk meg lépésröl lépésre, hanem folyamatos értékelés, újratervezés és válaszlépés szükséges. Ha változást tapasztalunk az üzleti környezetben, szinte azonnal kell rá találnunk egy helyes reakciót. Sokszor pedig nem látjuk előre azt, mi fog történni akár csak néhány hónap múlva (jó példa erre a koronavírus miatti helyzet).

Azt gondoljuk, hogy az agilis módszerek és eszközök a gyors reagálási képességnek az elsajátítását segítik, azonban ehhez szükséges, hogy a változásokra lehetőségként és izgalmas kihívásként tekintsen egy szervezet. A tagok közt legyen jól kialakult bizalmi kapcsolat, olyan csapatszellem, ahol a tagok rendelkeznek vállalkozói szemlélettel, és minden eszközük megvan ahhoz, hogy kamatoztassák kreatív képeségeiket. Ehhez nagyon fontos, hogy megfelelő vezetővel rendelkezzenek. A következő fejezetben ezt az úgynevezett „agilis vezetöt” és agilis szervezést fogjuk bemutatni.

\section{Az agilis vezető}

Agilis vezetőként egyidőben kell a buzdító (enabler) és a romboló szerepnek (disruptor) megfelelnie egy vezetőnek. (lásd 2. ábra) Ezt nevezi Simon Hayward agilis vezetési paradoxonnak. (Hayward, 2018) Ez azt jelenti, hogy egy vezetőnek egyszerre kell rákapcsolódnia a vezetettjeire, azaz jobban megértenie őket, és engedni, hogy azok kipróbálják saját ötleteiket és elképzeléseiket, ugyanakkor dolga az is, hogy lerombolja a vezetettjeinek negatív vagy káros és elavult gondolatait, hiedelmeit az üzletről és a munkavégzésről, amelyek csőlátást okoznának a csapat egyes tagjainál. A vezetőnek fel kell tudni ráznia vezetettjeinek gondolkodását, üdvözölnie kell az új ötleteket és lehetőségeket (akárhonnan származnak azok), és felborítania a status quo helyzetet. Ezzel tudja egy vezető biztosítani, hogy a szervezet vagy csapat képes legyen a változó körülményekhez gyorsabban alkalmazkodni.

2. ábra: Agilis vezetési paradoxon

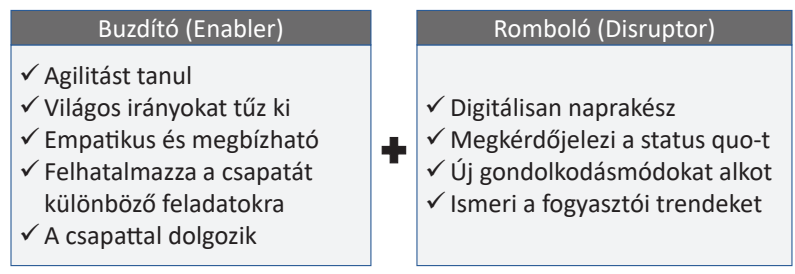

Forrás: Hayward, 2018, 10. old.
A buzdító oldalon a vezető olyan szervezetet alkot, amely képes válaszolni a gyorsan változó ügyféligényekre és a versenytársak viselkedésére. Ma már az emberek nem egy cégnek szeretnek dolgozni, hanem valamilyen célért, valamilyen felsőbb okból. (Hayward, 2018) Az agilis vezetők figyelnek arra, hogy megadják ezt az okot, és kitűzzék a követendő irányt, ezzel motivációt adva csapatuknak. Arra buzdítják a csoportjuk tagjait, hogy a változásokra hatékonyan válaszoljanak. Ennek érdekében arra törekszenek, hogy a döntéseket a fogyasztóhoz a lehető legközelebbi szinten hozzák meg. Ehhez képesek lemondani saját hatalmukról, illetve döntési jogaikról, és hajlandók azt átruházni vezetettjeikre, még akkor is, ha azok először elbuknak. Az agilis vezetők a bukásra tanulási lehetőségként tekintenek, ezért kísérletezésre és a határok feszegetésére biztatják a beosztottjaikat. Az esetleges kudarcok ellenére lelkesedésük, víziójuk, empatikus képességeik miatt a vezetettek hiteles vezetőként tekintenek rájuk.

\section{Agilis vezetőként egyidőben kell a buzdító (enabler) és a} romboló szerepnek (disruptor) megfelelnie egy vezetőnek.

Mindeközben ezen vezetők felismerik a változás (szervezeti, üzleti, értékesítési stb.) szükségességét, amely mindenképpen új alapokra fogja helyezni a szervezetet. Ezért aktívan keresik a lehetőségeket, hogy új működési modelleket implementáljanak, és ne maradjanak le a saját iparáguk „Uber pillanatáról”. ${ }^{3}$ Szeretik leépíteni a bürokratikus működést, támogatják az új szervezeti formákat és módszereket, és forszírozzák a csapatban (tribe) gondolkodást.

$\mathrm{Az}$ agilis vezetőkről általában elmondható, hogy energikusak, pozitívak a jövővel kapcsolatos várakozásaik, igen kreatívak, és csapatuktól is elvárják, hogy gyorsan alkalmazkodjanak a külső környezet változásaihoz. Fentiek miatt hajlandók magasabb rizikót vállalni, kockázatosabb projekteket megvalósítani és ezekkel áttöréseket elérni.

\section{Agilis csapatszervezési elvek}

Az agilitásnak nem csupán szemléletmódja és értékei vannak, hanem bizonyos szervezési módjai is. Természetesen ezek reflektálnak az agilis szemléletmódra, különböző agilis gyakorlatokra és eszközökre, illetve kölcsönhatásban is állnak ezekkel. Azt gondoljuk, hogy ezen szervezési elvek azért döntőek, mert ebben már jól mérhető, hogy egy szervezet mennyire agilis. Ha egy szervezet még csak az agilis eszközöket (a hagyma belsőbb halmazai) használja, akkor maximum az első szintet érte el az agilitásban, mivel ezen eszközök használatának előírása lehet egy szimpla (egyébként így akár kontraproduktív) vezetöi utasítás is. Ha azonban agilis csapatszervezési elvek és praktikák mentén szerveződik egy szervezet, az jól látható (akár mérhető is), ellenben azzal, hogy a vállalatban mennyire megtalálható, a szemmel és kívülről nehezen észlelhető agilis szemlélet (mindset). 


\subsection{Projektcsoportosulás}

Denning (2018) egyértelműen definiálja könyvében, hogyan és milyen elvek mentén kell szerveződnie egy agilis szervezetnek. Első szabálya az agilitáshoz a „kis csapatok törvénye” (The Law of the Small Teams). Eszerint kis, keresztfunkcionálisan megszervezett, autonómiával rendelkező és önszervezésre képes csapatoknak kell alkotniuk a szervezetet, amelyek olyan emberekből állnak, akiknek ugyanolyan szemléletük van. Ezen csapatok rövid, fókuszált (munka) ciklusokban (short cycle) dolgoznak relatíve kis feladatokon, erősen fókuszálva, és visszajelzéseket kapva munkájukra közvetlenül az ügyfelektől vagy a végfelhasználóktól.

Természetesen ilyen csapatok eddig is léteztek, sőt, a legtöbb nagyvállalatban mindig megtalálhatók voltak. Talán sokan részesei lehettünk pályánk során olyan projektcsapatoknak, ahol a kommunikáció gördülékeny volt, mindenki lelkesedett, ahol viszonylag nagy autonómiát éreztünk, mint csapat együtt döntöttünk mindenről, ahol megbízhattunk egymásban, és ahol szemtől szemben megvitathattuk különböző nézeteinket. Egyszóval a csapat közösen és egyéni szinten is „flow” állapotba került. (Csíkszentmihályi, 1990)

Az agilis szervezés igazi nagy kihívása, hogy hogyan lehet ezt az állapotot egy szervezetben konstans módon fenntartani és kiterjeszteni a szervezet egészére. Sokkal jobban jár egy szervezet, ha a teljes szervezet ilyen csapatokból áll, és nem csak néhány „elit csapat” működik így, mert egy agilisan müködő csapat munkáját (pl.: egy projekt-team) hátráltathatja a többi tradicionálisan szervezett csapat (pl.: HR), mivel máshogy dolgoznak, és nem értik meg egymást, ha különböző szemlélettel rendelkeznek (Denning, 2018). Azonban teljes mértékben agilissá alakítani egy tradicionális szervezetet nagyon nehéz feladat, és eddig igen kevés tanulmány jelent meg a témában (pl.: Brosseau et. al., 2019)

Az agilis szervezés központi eleme tehát az agilis csapatokon keresztüli működés. Hogyan, milyen elvek mentén müködnek ezek? Elöször is a csapatok kis munkacsomagokon (small batches), jól lebontott, de önmagában is értelmezhető, a felhasználóknak értéket teremtő folyamatokon, projekteken dolgoznak. Ennek az elvnek az alkalmazásával a haladás még nagy és komplex projektek esetében is látható

Ezen csapatok 2-3-4 hétig dolgoznak valamin, legkésőbb ennyi idő után közvetlen visszajelzést kapnak munkájukról. Míg más cégek nagy projekteket buknak el azért, mert túl sok ismeretlen és változó volt egy-egy projektben, addig az agilis szervezetek kis csapatai rövidebb ciklusokban dolgoznak, kisebb feladatokon, gyors visszajelzést és validációt kapva munkájukra. Ezt úgy kell elképzelni, mintha egy nagy és lassú csatahajó helyett sok kis, gyors naszádunk lenne, amelyek sokkal jobban reagálnak a csata eseményeire. (Denning, 2018)

\subsection{Projektnormák}

Ezen kis csapatok keresztfunkcionálisak, azaz tagjaik különböző területek szakértői, ami lehetővé teszi számukra, hogy ne kelljen sokszor „külsős” tanácsadót bevonni a munkába. A csapatok (team), néhány helyen csoportnak (group) vagy angolul „squad”-nak nevezett egységek, az ökölszabály szerint hét plusz/mínusz két föből állnak, ugyanis ennél nagyobb csoport már nem tudna eredményesen együtt dolgozni. (Denning, 2018)

Ezen csapatok számára biztosítani kell az autonómiát. Ha egyszer egy „rövid munkaciklus” irányát a vezetés kijelölte, utána nem szabad beleszólnia és irányítania a csapatot, hiszen ez felesleges adminisztrációs terheket és a munka megzavarását jelentené. Ha egyszer egy ilyen rövid ciklus elindult, akkor onnantól az irányítás a csapaté

Fontos szabály a kis csapatok működésére nézve, hogy a kijelölt feladatnak vagy eredménynek ténylegesen és 100 százalékban készen kell lennie. (Nagy szervezetek sokszor azért nem képesek gyorsan reagálni, mert sok idejük megy el olyan projektekre, amelyek „majdnem készek”, de nem teljesen, ezért aztán hozzáadott értékük sincs.) A feladat kijelölése és méretezése (tehát, hogy az kellően kicsi legyen), és a „kész” állapot pontos definiálása ezért kulcsfontosságú.

\subsection{Projektkommunikáció és transzparencia}

Másik nagyon fontos tulajdonságuk ezeknek a csapatoknak, hogy teljes mértékben átláthatóan dolgozzanak. Minden tag minden pillanatban legyen tisztában azzal, hogy hol tart a teljesítésben a csapat, ki mit csinál az adott napon, és hogy mikor minek kell jönnie. Ezeket segítik az olyan eszközök, mint a reggeli, fix időben tartott általános státuszmegbeszélés, vagy a mindenki számára átlátható offline tábla, amelyen jelölve vannak a folyamatok.

Továbbá a ciklus végén nagyon fontos, hogy az elkészült produktumról érkezzen közvetlen visszajelzés a végfelhasználótól (akár külső, akár belső is legyen az), illetve, hogy a csapat visszatekintsen a ciklus során végzett munkájára, tanuljon a hibákból, és következtetéseket vonjon le a jövőre vonatkozóan.

\subsection{Csoportkohézió}

Végezetül az egyik legfontosabb mérőszám az agilis csapat megítélésekor, hogy a tagok mennyire élvezik a munkát ezekben a csapatokban. Ez meglepő lehet, hiszen a tradicionális menedzsmentben általában olyan szavakat használunk, hogy „eredményes” (efficient) vagy „hatékony” (effective). Azonban azt gondoljuk, hogy hosszú távon az a csapat tud magas hozzáadott értéket adni, amelyben a tagok jól érzik magukat, ahol lelkesednek azért, amit csinálnak, és szívesen teszik a dolgukat. (Nem mellesleg ezen munkahelyek igen vonzók a fiatal tehetségek számára). Mire van szükségük a csapatoknak, hogy örömteli legyen a működésük, és jól, magas hozzáadott értéket elöállítva dolgozzanak?

Meglepő módon nem azok a csapatok teljesítenek a legjobban, ahol az egyének kvalitásainak aggregált összege a legmagasabb. Egy Google-nál végzett kutatás alapján öt dinamikai kulcstényezőt azonosítottak, amely megtalálható a legjobban működő csapatokban. (Rozovsky, 2016) 
1. Pszichológiai biztonság, azaz, hogy a csapat tud-e bizonytalanság és zavar nélkül kockázatot vállalni.

2. Megbízhatóság, azaz, hogy a csapat tagjai számíthatnak-e egymásra abban, hogy mindenki időben és megfelelő minőségben elvégzi a munkáját.

3. Struktúra és egyértelműség, azaz, hogy a csapat céljai, szerepei és végrehajtási tervei egyértelmüek-e.

4. A munka értelme, azaz, hogy a csapat tagjai valami olyanon dolgoznak, ami személyesen is motiválja őket.

5. A munka hatása, azaz, hogy alapvetően hisznek a csapattagok abban, hogy a munkájuk fontos és hasznos másoknak.

Ezen kulcstényezők meglétét sok minden befolyásolja, nagyon fontos, hogy milyen személyiségű és kvalitású embereket teszünk egy csoportba. Ez talán a legnehezebb feladat, mikor létrehozunk egy új csapatot.

Az egyik legfontosabb mérőszám az agilis csapat megítélésekor, hogy a tagok mennyire élvezik a munkát ezekben a csapatokban.

Összefoglalva tehát: az agilis csapat, amely alapvető építőköve az agilis szervezeteknek, sok mindenben eltér a klasszikus értelemben véve bürokratikusan működő szervezetektől.

A 3. ábrán is láthatjuk a fö különbségeket. Míg a klasszikus szervezetek belülre fókuszálnak, a meglévő folyamatokból és eszközökből akarják kihozni a maximum hatékonyságot (ezzel értéket teremtve a tulajdonosoknak), addig az agilis szervezetek kifelé fordulnak, új kihívásokat keresnek, és új problémákra adnak megoldásokat, így értéket szállítanak ügyfeleiknek.

3. ábra: Tradicionális vs. agilis csapat
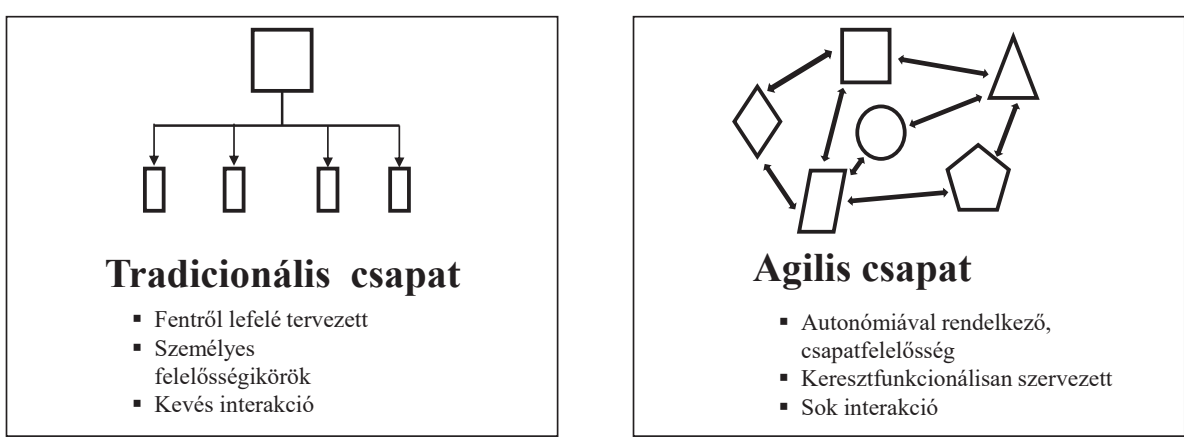

Forrás: Denning, 2018, 15.old.

\section{A tradicionális és az agilis szervezet közötti eltérések a folyamatszervezésben}

A következőkben megvizsgáljuk, milyen módszerei vannak az agilis projektmenedzsmentnek és közelítési módnak. Ahhoz viszont, hogy megértsük, miben különbözik az agilis folyamatszervezés és megközelítés a hagyományostól, illetve mindez hogyan valósul majd meg a gyakorlatban, szükségesnek látjuk a tradicionális működés bemutatását is.

\subsection{Projektmenedzsment}

Vessük most össze a tradicionális és az agilis projektmenedzsment elveit.

\section{Tradicionális projektmenedzsment}

„A projektmenedzsment elveit a különbözö iparágakban, illetve állami szinten is alkalmazzák, mivel a vezetök felismerték, hogy vállalatuk egyre inkább projektek által vezérelt szervezetté alakul át." (Verzuh, 2006, 17. old.) A könnyebb megértés érdekében rögtön az elején definiáljuk a projektet. „A projekt olyan feladatok vagy tevékenységek sorozata, amelyeknek konkrét célja, meghatározott kezdési és befejezési dátuma van, forrásokat fogyasztanak, bizonyos költségvetéssel rendelkeznek és többfunkciósak." (Sarkar - Locatelly, 2017, 5. old.) A világ folyamatos változásaira a vállalatok innovációval (termék, technológiai stb.) igyekeznek reagálni, ami egyben új projektek indítását is jelenti. Elkerülhetetlenné válik emiatt ezeknek a projekteknek az összefogása és koordinálása. Projektmenedzsmentet alkalmazva a vállalatok komoly gazdasági előnyre tehetnek szert azokkal a versenytársakkal szemben, amelyeknek a méretgazdaságosság vagy a hatékonyság határozza meg a működését, ugyanis a projekt lehetővé teszi a változások gyors lekövetését. A projekt sikerességét mutatja továbbá, ha rendre szem előtt tartják a projektmenedzsmentben használatos acélháromszög elemeit (hatókör, idő, költség, minőség, lásd 4. ábra), illetve ha már rögtön a projekt kezdetekor minden abban részt vevő (megrendelő, menedzser, projektteam) számára egyértelműek és elfogadottak a projekt céljai, valamint a projekt teljes folyamatára kiterjedő költség-, idő- és erőforrásterv készült az indulást megelőzően. A projekt futásának ideje alatt pedig elengedhetetlen az állandó és eredményes kommunikáció (hivatalos vagy akár informális módon), a folyamat alapos dokumentációja, a menedzsment támogatása, azaz a projektkörnyezet biztosítása és a projektcsapat tagjai feladat- és felelősségkörének meghatározása, illetve a hatókör követése és az abban történő változások megértése. A projekt lezárása is akkor történik meg, amikor a megrendelő elfogadja a terméket. Ekkor ajánlott a kötelező adminisztratív feladatokon túl kiértékelni a teljes projektet, amiből tanulni és fejlődni tudnak mind a projektben részt vevők, mind pedig a vállalat. (Verzuh, 2006) 
4. ábra: Acélháromszög

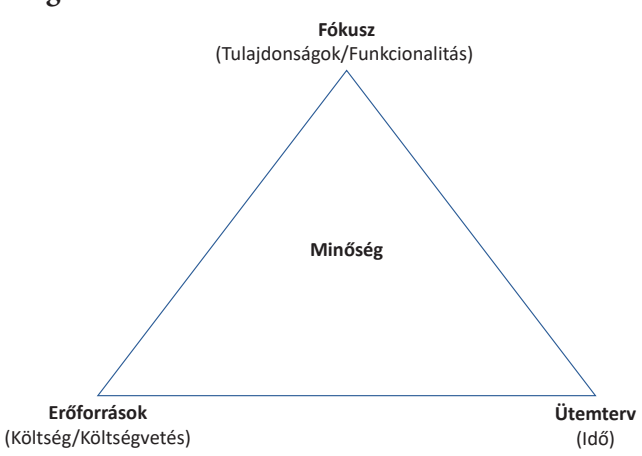

Forrás easyprojekt.hu

\section{Agilis projektmenedzsment}

Az agilis projektmenedzsment ezzel szemben vagy éppen ezt meghaladva előtérbe helyezi az Agilis Kiáltványt (Beck et. al., 2001) és az agilis szoftverfejlesztési elveket, és azok mentén kívánja megvalósítani a kitűzött projektet. A projektteam a projektmenedzser személyes megkeresése helyett önszerveződő módon alakul meg, tagjai túllépnek az acélháromszög számukra korlátozó elemein. Fontos szempont, hogy a környezet változására agilis módon, azaz minél gyorsabban reagáljanak, ezért nem kötik magukat szorosan az eredeti fókuszhoz: a megrendelő folyamatosan változó igényei szerint fejlesztik személyre szabottan a terméket, csak a források és az idő jelenthet korlátot. A hatékony mủködést és a minél rendszeresebb szállítást továbbá a formális kommunikáció és más projektet lassító teendő (részletes dokumentáció, szolgáltatási szintű megállapodások) mellőzésével érik el. (Sarkar - Locatelly, 2017)

\subsection{Közelítési módok}

A projektmenedzsmenten belül három közelítési módot, munkaszervezési módszert különböztetünk meg jelenleg: a tradicionális közelítési módot, a kritikus láncot és az agilis közelítési módot. A kritikus lánccal, amely szintén tradicionális alapokon nyugszik, ebben a dolgozatban nem foglalkozunk, mert egyrészről széles körben nem elterjedt, a későbbiekben sem lesz releváns, illetve a tradicionális és az agilis megközelítés összehasonlítása jól szemlélteti majd a hasonlóságokat és a különbözőségeket.

\section{Tradicionális közelítési mód}

A projektmenedzsment egyik legismertebb megközelítése a tradicionális, azaz a waterfall (magyarul: vízesés) mód. Találó a neve, jól írja le a folyamat mủködési elvét, a szekvenciális megközelítést: ahogyan a víz esik le a kiálló sziklákról, úgy követik egymást a projektek - akkor lépnek az egyik szakaszból a másikba, amikor az előző már befejeződött. Öt szakaszból áll: a Követelmények fázisban összegyűjtik az összes igényt és specifikációt, amelyek az alapját képezik majd a Tervezés szakasznak, ahol a rendszermegoldásokat részletesen kidolgozzák. Ezek mentén kezdődik el a Megvalósítás fázis, majd, amikor ez befejeződött, lép a projekt a Hitelesítés szakaszába, ami a termék tesztelését jelenti. Végül a projekt záró szakasza a Karbantartás, amikor a hibák javítása, valamint terméktámogatás (support) történik. Ennek a szakasznak a végén kapja meg az ügyfél a terméket, ami jól mutatja a waterfall folyamat merevségét. Mivel a szakaszok között nincsen visszacsatolási lehetőség egy korábbi szakaszhoz, menet közben nehezebben lehet módosítani az eredeti specifikáción (scope change), így amennyiben változna a megrendelő igénye, azt már csak formális úton, teljes körủ dokumentációval vagy egy teljesen új projekt keretében lehetne megvalósítani, megannyi erőforrás (újbóli) bevonásával. (Sarkar - Locatelly, 2017)

\section{Agilis közelítési mód}

A szervezeti agilitást, az agilis termékfejlesztést és a munkavállalók agilis munkavégzését különböző módszertanok és eszközök segítik elő, amelyek a különböző területeken teszik hatékonyabbá a mindennapi munkát. A célkitűzéstől kezdve egy új termék kialakításán keresztül a termékfejlesztésig, mindenhez találunk megfelelő segítő eszközt. Ezek közül most azokat mutatjuk be, amelyek a biztosítótársaságnál nagy mértékben segíthetik a mindennapi munkát.

\section{Scrum}

A Scrum módszer lényege, hogy a komplex nagy feladatot kicsi, szállítható elemekre osztjuk, azokat priorizáljuk, és kis méretű, keresztfunkcionális csapatokkal megvalósítjuk. A rendelkezésünkre álló időt fix ciklusokra bontjuk (sprintek), amelyeknek a végén leszállítjuk az adott iterációra tervezett inkrementumokat. Ezt integráljuk a nagy feladat egészébe, illetve javítjuk és fejlesztjük folyamatainkat, az elkészült produktumokat teszteljük és jóváhagyjuk, valamint újraértékeljük a prioritásokat az eddigi tapasztalatok alapján. Míg a waterfall típusú tradicionális termékfejlesztésnél nincs lehetőség a produktum egy-egy funkciójának tesztelésére és jóváhagyására a „Kivitelezés” fázis lezárulta előtt, addig a Scrum módszertanban meghatározott kis, szűkített fókuszú feladatok lehetőséget adnak erre. (Kniberg - Skarin, 2010)

A teljes folyamat jól strukturált - a módszer szerepköröket határoz meg, és jól definiálja a megvalósítás minden egyes lépését is. A szerepeket két nagy csoportra oszthatjuk: disznókra és csirkékre, amelyeknek kapcsolatát, viselkedését és hozzáállását a feladathoz, az alábbi vicc írja le leginkább: 
A disznó és a csirke mennek az utcán. Egyszer csak megszólal a csirke:

- Te, nyissunk egyéttermet!

Mire a disznó:

- Jó ötlet, mi legyen a neve?

A csirke gondolkozik, majd azt feleli:

- Nevezzük Sonkástojásnak!

Erre a disznó:

- Nem tetszik valahogy, mert én biztosan mindent beleadnék, te meg épp hogy csak részt vennél benne.

(Angol vicc fordítása)

A Scrumban a disznók közé tartozik a terméktulajdonos (Product Owner), a fejlesztőcsapat (Project Team) és a moderátor, azaz a scrum mester (Scrum Master). A terméktulajdonos feladata a megrendelő képviselete, a termékkel kapcsolatos részletes funkciólista (product backlog) leírása és priorizálása, valamint a követelmények, inkrementumok meghatározása, majdan el(nem)fogadása. A fejlesztőcsapat egy önszerveződő, keresztfunkcionális csapat, amely maga határozza meg a módját, hogyan készít és szállít a backlogból inkrementumokat. Bár a csapat tagjai a projekten belül dolgozhatnak a saját szakterületükön - alkalmazva a speciális tudásukat -, a módszer lehetővé teszi, hogy az inkrementumok sikeres szállítását szolgálva a tagok túllépjenek saját szakterületükön. Emiatt valósulhat meg az is, hogy a felelősséget nem a tagok vállalják egyenként, hanem az egész csapatra hárul. A harmadik szerepkör végül pedig a Scrum Master, aki a fejlesztőcsapatot támogatja, mentorálja és facilitálja. Feladata a Scrum keretrendszer szabályainak betartatása a csapattagokkal, a projekt megvalósulását gátló akadályok elhárítása, valamint a csapat megóvása a külső káros tényezőktől, hogy a csapat tagjai a Scrumban meghatározott feladatra koncentrálhassanak. Utóbbira példa, amikor a Scrum Masternek fel kell oldania azt a konfliktust, amikor a munkatársak Scrumon kívüli feladatai miatt erőforráshiány (időhiány vagy prioritásbeli kérdés) lép fel. (Schwaber - Sutherland, 2017)

A Scrumban a csirkék szerepét töltik be a felhasználók, visszajelzéseikkel segítik a termékfejlesztést, az üzleti szereplők, akik lehetővé teszik a projekt létrehozását, és akiknek a haszna a termék sikeres értékesítéséből származik, valamint a menedzserek, akiknek a feladata a projekt munkakörnyezetének biztosítása. Ök nem részei a Scrum folyamatnak, ennek következtében felelösségük sincs.

A Scrum folyamata a következőképpen alakul: a terméktulajdonos priorizálja a backlogot, amiből a Fejlesztőcsapat a sprint megtervezésekor kiválasztja a következő ciklusban megvalósítandó elemeket (sprint backlog), majd elkezdődik azoknak a megvalósítása, a sprint időszaka. A csapat a Scrum Master vezetésével minden nap elején (fix helyen és időpontban) stand upot tart (daily scrum), illetve idővel megkezdődik a következő iteráció előkészítése (backlog refinement). A sprint végén kétféle értékelést tart a csapat: egyrészről bemutatja az inkrementumokat a terméktulajdonosnak (sprint review), amiket elfogadásuk esetén beépítenek a termékbe, illetve önértékelést végeznek (sprint retrospective) a folyamatok fejlesztése és a gyengeségek kiküszöbölése végett. (Schwaber és Sutherland, 2017) (lásd 5. ábra)

Talán a Scrum módszeren szemléltethető leginkább az agilis projektmenedzsment szabadsága, hiszen a Fejlesztőcsapat addig iterál, ameddig a megrendelő elvárásainak nem felel meg a végtermék, vagy ameddig az a költségeket fedezni tudja. Sokszor a folyamat közben a fókusz is változhat, ami újabb időt és forrásokat igényelhet. Amennyiben nincsenek rögzítve a rendelkezésre álló egységek, addig - bár agilis termékfejlesztést hajtunk végre, és a végső termék minősége is garantálható - nem lesz hatékonyabb más nem-agilis módszernél.

5. ábra: Sprint folyamat

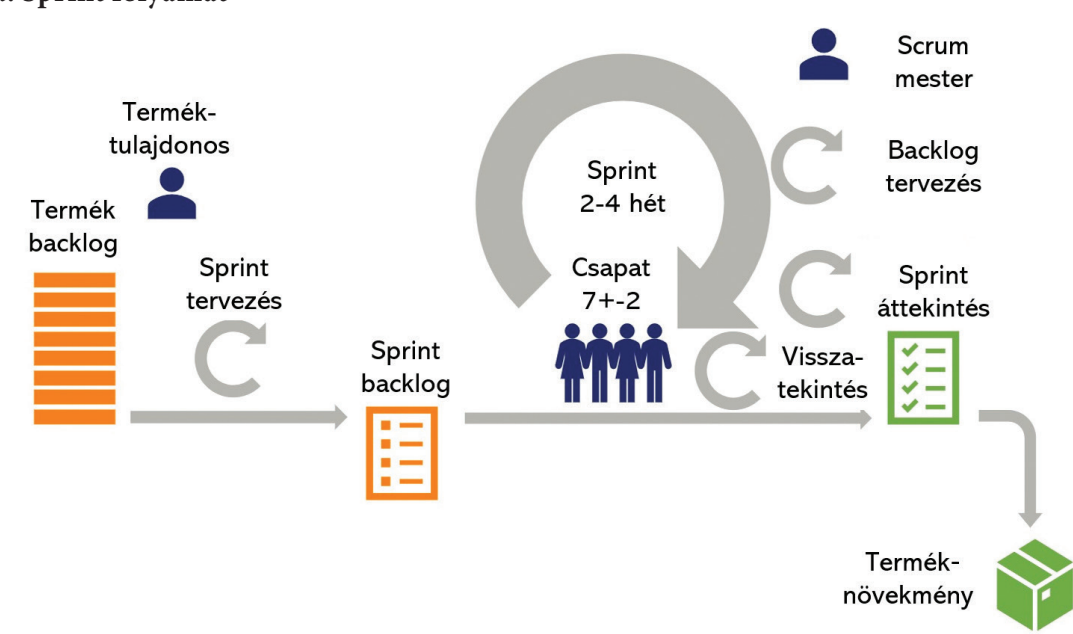

Forrás: ProMan Consulting, 2019

\section{Kanban}

A Kanban (Japánból ered, magyarul kártyát vagy táblát jelent) egy pull módszer, a Just-in-Time rendszer alapja, amely költségcsökkentési és optimalizációs célokból meghatározza, korlátozza a folyamatban a végrehajtás alatt álló feladatok (work-in-progress, azaz WIP) számát. Vizualizálását a Kanban-tábla segíti, amely tartalmazza a teljes munkafolyamatot és az adott fázisokhoz tartozó feladatszámkorlátokat. (lásd 6. ábra) Ez teszi lehetővé, hogy az önszerveződő csapat ne vesszen el a sok feladat között, és csak akkor kezdjen új feladat elvégzésébe, amennyiben a következő fázisban felszabadult egy hely, ezzel is meggátolva a túltermelést. A Kanban egyszerű rendszer, ugyanakkor elsajátítása és alkalmazása nagy önfegyelmet igényel. Viszont, ha sikeresen véghez visszük, folyamatainkat és a rendszert is optimalizálni tudjuk a különböző méröszámok mentén (pl. átfutási idő). Kanbant leginkább az IT, a HR, az értékesítés és a gyártás területen alkalmazunk. (ProMan Consulting, 2020) 


\section{6. ábra: Kanban-tábla}

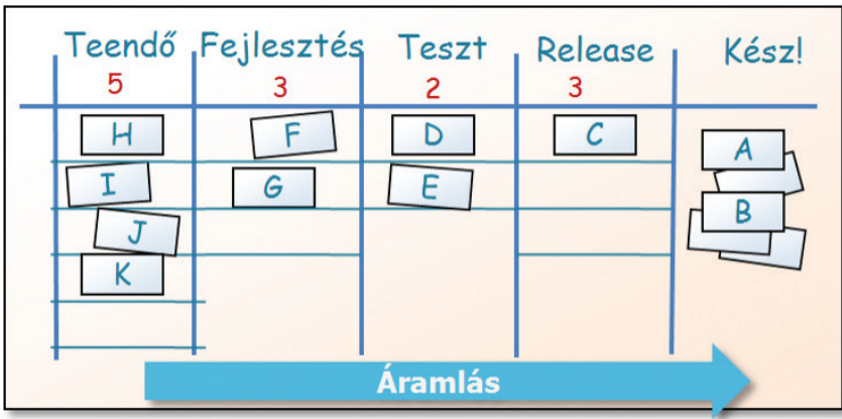

Forrás: Kniberg - Skarin, 2010, 20. oldal

Bár úgy tűnhet, hogy a Kanban és a Scrum között nagy eltérések vannak (pl. míg a Scrumban a WIP indirekt módon kerül meghatározásra (sprintenként), addig a Kanbanban közvetlenül korlátozott; Scrumban priorizált termék backlog, Kanbanban a priorizálás opcionális, stb.), mégis hasonlóak (pl. mindkettőnek a korai és gyakori szállítás a célja; mindkettő önszerveződő csapatokon alapszik), sőt kiegészítik egymást, és együtt is alkalmazhatóak (pl. egy sprintben alkalmazzuk a Kanban-táblát). Ezt nevezzük Scrumbannak, amely szintén népszerü az agilis módszereket alkalmazó vállalatoknál, csapatoknál. (Kniberg - Skarin, 2010)

\section{Design Thinking}

A Design Thinking olyan eszköz, amely új aspektusból segíti a vállalatokat egy termék/ szolgáltatás kialakítása vagy fejlesztése során. A 7. ábrán jól látszik, a startupok 42 százaléka azért megy csődbe, mert nem térképezik fel előre, hogy valós piaci igény mutatkozik-e az ötletük iránt. A Design Thinking ezt elkerülendő a fogyasztói igényeket helyezi a fókuszába, így próbálja csökkenteni a piaci bukás esélyét.

7. ábra: A startupok bukásának 20 leggyakoribb oka (részlet)

$$
101 \text { startup csőd utáni elemzése alapján }
$$

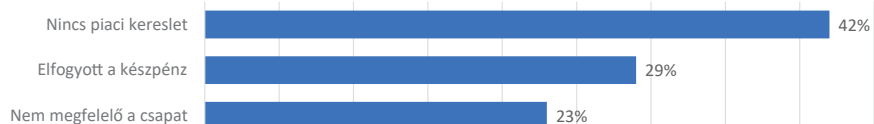

Forrás: cbinsights.com

A Design Thinking folyamatát három fázisra lehet osztani. (lásd 8. ábra) A kezdeti Inspiráció fázisban a célcsoport fogyasztóinak problémáival kapcsolatos empátia, a megértés az elsődleges feladat. Meg kell határozni az elérendő célt, amelynek alapján protoperszónákat hozunk létre, ezen keresztül tanulmányozni lehet a potenciális ügyfeleket és problémáikat. Ezeket a betekintéseket tovább mélyíthetjük storyboard és journeymap elkészítése által, azaz ábrázoljuk, hogy a felvázolt protoperszónák jelenleg hogyan oldják meg a problémáikat a piacon jelen lévő versenytárs termékekkel, illetve a fogyasztó milyen fóbb szakaszokon megy végig a problémafolyamatban. Ezek alapján lehet kialakítani saját lehetőségeinket, hogy aztán a második, Fogalomalkotás fázisban elkezdődhessen az ötletelés. Ötleteket és megoldásokat generálunk, amelyekből a legjobbakat kiválasztjuk és kidolgozzuk, saját storyboardot hozva létre. A legvégén a Megvalósítás fázisban a megszületett ötleteket megvalósíthatóság és hozzáadott érték szerint egyaránt priorizáljuk, létrehozzuk a termék/szolgáltatás prototípusát, ami már életképes (minimum viable product), és teszteljük a célcsoporton. Az ebből szerzett információk alapján lehet a felmerülő hibákat és gyengeségeket kiküszöbölni, illetve javítani, valamint meghatározni a termék értékajánlatát. A módszer használatának zárásaként pedig összegezzük ezeket a tapasztalatokat, és döntünk a hogyan továbbról. (Mahmoud-Jouini et al., 2019)

8. ábra: A Design Thinking folyamatának alapmodellje

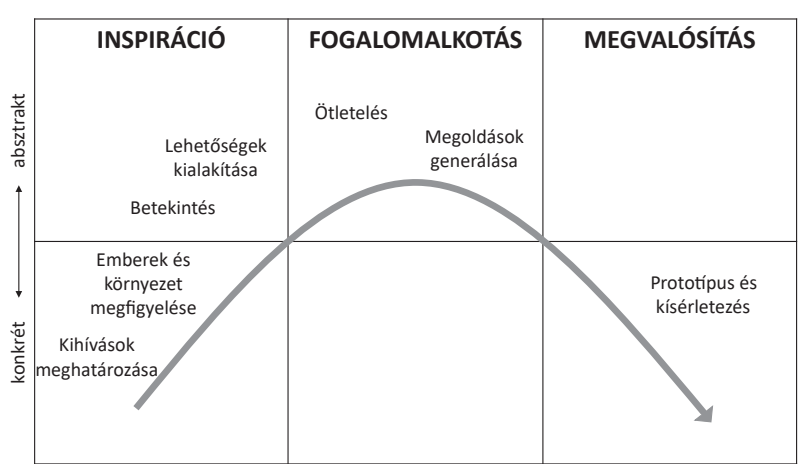

Forrás: Mahmoud-Jouini et al., 2019

\section{OKR-rendszer}

Az OKR-rendszer egy agilis célkezelő keretrendszer, amely segít a vállalat stratégiájának követésében, növeli a fókuszt és az átláthatóságot, valamint elősegíti a cég és a munkatársak közös céljainak összehangolását. Az OKR két részből tevődik össze: ambiciózus, kvalitatív célok (Objectives), illetve jól mérhető, kvantitatív kulcseredmények (Key Results) meghatározásából. Míg az első esetben a „Mi a célom?”, utóbbinál a „Mit kell teljesítenem, hogy elérjem a célom?” kérdést kell megválaszolnunk, amit megtehetünk a vállalati hierarchia minden szintjén. Vállalati, team és egyéni szintű OKR-eket határozhatunk meg, amelyek az alábbi „okos” (SMART) módon, a közvetlen felettessel közösen kerülnek összeállításra:

- Specific (konkrét): A célok egyértelműek, és irányokat határoznak meg, amelyek teljesülését a kulcseredmények tovább pontosítják. 
- Measurable (mérhető): A kulcseredményeket mérhető adatok alapján határozzuk meg, amelyek alapján kiértékelhetjük a cél teljesülését.

- Achievable (elérhető): Az OKR-eket a rendelkezésre álló idő és erőforrások tekintetében kell meghatározni. A céloknak ambiciózusoknak kell lenniük, hogy a egyént inspirálják. Ebből is következhet, hogy egy 70-80 százalékos időszaki teljesítmény már jó eredménynek számíthat.

- Relevant (lényeges): Az OKR-eknek minden szinten illeszkedniük kell a magasabb szintü célokhoz, amelyek a vállalat stratégiájából eredeztethetők, és annak sikeres megvalósításához vezetnek.

- Time-bound (időhöz kötött): Az évet ciklusokra osztjuk., amelyek végén ellenőrizzük a kitűzött célok teljesülésének mértékét, illetve az új ciklusra új OKR-eket határozunk meg. A különböző szinteken eltérő hosszúságúak lehetnek a ciklusok - míg egy vállalati OKR-t akár egy évre is meghatározhatunk, addig a team/egyéni OKR-eket általában negyedévente állítjuk össze.

Amennyiben a kitűzött OKR teljesülésének értékelésekor 50 százaléknál kisebb értéket kapunk, át kell tekinteni a folyamatokat és a módszereket, és meg kell vizsgálnunk, hogy mi okozta a nehézségeket. 90 százalék feletti teljesítés esetén pedig azt kell átgondolni, hogy nem volt-e túlságosan könnyen teljesíthető a kitüzött cél. Ez esetben a következő ciklusban ambiciózusabb OKR-t kell összeállítanunk.

Az OKR teljesen transzparens rendszer, mert egyrészről nem változtathatunk időszak közben sem a célokon, sem a kulcseredményeken, másrészről pedig teljesen nyilvános - mindenki látja az összes OKR-t a vállalaton belül. Ez világossá teszi a munkatársak számára, hogy merre halad a vállalat, illetve ezáltal könnyebben segíthetünk a másiknak a céljai elérésében. Így ráadásul az is előfordulhat, hogy egy cél több embernél vagy teamnél is megjelenik - valószínüleg más kulcseredményekkel.

Az OKR-rendszer nem alkalmas teljesítményértékelő-rendszernek, és nem is lehet soha ily módon alkalmazni, hiszen a magunk elé kitűzött célokat mi magunk határozzuk meg, majd pedig értékeljük. (Maasik, 2018) Ugyanakkor éppen, emiatt motiválóan is hathat a saját teljesítményünkre, hogy az adott ciklusban a saját magunk által kitüzött célt valósíthatjuk meg.

\section{A módszertanok és eszközök összehasonlítása}

Megismerve a tradicionális és agilis közelítési módokat, talán legjobban egy sportból merített példán keresztül lehet leírni a közöttük lévő legnagyobb különbséget. Bár mindkettő csapatmunka, de amíg a vízesés mód olyan, mint a váltófutás, addig a Scrum olyan, mint az amerikai foci vagy a rögbi. Míg előbbi esetben a csapattagok egymás után futnak, és nem tudnak segíteni a másiknak a jobb teljesítmény elérésében, addig a Scrumban - amely szakkifejezés a rögbiben (dülekedésként lehetne fordítani) - együtt játszik a csapat, és úgy halad a kitüzött cél felé, szakaszonként (ciklusonként), újból és újból csak a következő kis lépést teljesítve, majd kiértékelve. Ettől függetlenül a vízesés közelítés jelenleg még mindig az elterjedtebb, hiszen az agilis meg- közelítés még csak most van kialakulófélben. Nincsenek egzakt meghatározásai, nem lehet még pontosan definiálni. Fontos azt is megemlíteni, hogy az agilis módszertanok különböző célokra alkalmazhatóak: míg a Design Thinking a „Milyen terméket fejlesszünk?”, addig a Scrum vagy a Kanban a „Hogyan fejlesszünk terméket?” kérdésre adnak új választ. És mindezeknek ad keretet az OKR, amely időszakokra bontva meghatározza a termék életútját az ötleteléstől az élesítésig.

Bár mindkettő csapatmunka, de amíg a vízesés mód olyan, mint a váltófutás, addig a Scrum olyan, mint az amerikai foci vagy a rögbi.

\section{Konklúzió}

Az agilitás felé nyitó vállalatok többsége az elején jár az agilis szervezetté válás útján. Az agilitási rétegek alapján sokuk még csak a könnyű lépéseket teszi vagy tette meg: az eszközöket és a folyamatokat, valamint a gyakorlatokat tanulja vagy gyakorolja. Ez a szervezeti agilitás, ez egy képesség. Képesek vagyunk agilis módon reagálni a környezetünk változásaira. El van ültetve a gondolat a munkatársaink fejében, rendelkezésre állnak az eszközök és módszertanok, de csak addig vagyunk agilisak, amíg ezeket használjuk. Utána kilépünk belőle, és folyamatainkat az eddig megszokott, hagyományos módon valósítjuk meg. Ugyanakkor igyekszünk alkalmazni az egyes agilis elemeket munkánk során, amiből hibrid megoldás jön létre. Ahhoz viszont, hogy szintet lépjünk, elengedhetetlen, hogy mi magunk, a kollégáink és a környezetünk is teljesen megértsük és magunkévá tegyük az agilis szemléletmódot, hogy ez határozza meg a tetteinket, döntéseinket, vezetési stílusunkat.

Az agilitás egy megoldás, de az agilissá válás egyben hatalmas és kockázatos kihívás is a szervezetek számára. Lehetőséget kínál arra, hogy nagy szervezetek is sikeresen válaszolhassanak és alkalmazkodhassanak a változó világ elkövetkező kihívásaira, és biztosítsák a hosszú távú fennmaradásukat, de ezzel egy időben, főleg rövid távon, az agilis átalakulás nagy erőfeszítéseket és szemléletformálást követel meg.

Az agilitás egy megoldás, de az agilissá válás egyben hatalmas és kockázatos kihívás is a szervezetek számára.

Nem kevés bátorságra van szükség ahhoz, hogy egy kompletten új gondolkodást és működési módot implementáljunk, ráadásul nem kaphatunk biztos receptet, amely megmutatja A-Z-ig, hogyan váljunk agilissá. Mivel minden szervezet más és más, ezért mindenkinek a saját megoldásait és a saját átalakulási útját kell megtalálnia. Ez pedig bizonyosan azt jelenti, hogy lesznek kudarcok, bukások és tanácstalan pillanatok ezen az úton, de véleményünk szerint hosszú távon a legtöbb szervezet számára a túléléshez elengedhetetlen, hogy agilissá váljon. Ehhez nyújtanak segítséget azok az ökölszabályok, amelyeket fentebb bemutattunk. 
Szeretnénk megjegyezni: annak ellenére, hogy az agilitás ma nagyon „trendi” hívószó, nem gondoljuk azt, hogy a világ különböző kultúráiban és a gazdaság különböző iparágaiban egyformán és sikerrel lehet agilissá válni. Véleményünk szerint néhány esetben a nagymértékü agilitásra való törekvés kontraproduktív is lehet, ezért nagyon alaposan meg kell fontolni, föleg olyan piacokon, ahol a hibázás sokba kerülhet (pl.: az egészségügyben), hogy mit, hogyan és a szervezetnek mely területein alkalmazunk ezekből a technikákból és szervezési módokból.

Következtetések a biztosítási szektorra nézve:

A biztosítási szektor szereplőinek meglátásunk szerint mindenképpen agilissá kell válniuk, hiszen termékeik „virtuálisak”, és az igények is gyorsan változnak. A biztosítási szerződések teljesen digitalizáltak, hiszen az ügyfelek egy „ígéretet” vásárolnak arra nézve, hogy baj esetén a kárukat megtérítik. Ha a kiskereskedelmi óriás Amazon, amely sok termékkel kereskedik, technológiai vállalatként tekint magára, annál inkább így kéne definiálniuk magukat a biztosítóknak is.

Véleményünk szerint a tradicionális biztosítók a hírnevükkel és a beléjük vetett bizalommal tudnak szembe szállni feltörekvő technológiai vállalatokkal a távoli jövőben. Azonban ha ezek a vállalatok kellő időben nem válnak technológia fókuszúvá, akkor ez a versenyelőny el fog tűnni, hiszen a fiatal generációk már a Big Tech vállalatokban is megbíznak. A biztosítóknak tehát működésben példát kell venniük ezen technológiai vállalatokról, melyeknek döntő többsége agilisan müködik.

Fontos megjegyezni azonban, hogy rövid távon súlyos veszteségeket realizálhatunk, ha nem vesszük figyelembe, hogy nincs még minden technológiára és innovációra igény a magyar piacon. Több ígéretesnek tünő innováció (pay as you drive, pay as you go technológiák) megelőzték a magyar piac igényeit, ezért nem eredményeztek sikereket. Ezen kudarcok az anyagi veszteség mellett azért is károsak, mert egy vállalat azt a következtetést vonhatja le, hogy felesleges ennyire innoválni, és innovatív termékeket piacra vinni, ezzel pedig hosszú távon mindenképp rosszul jár. Ha azonban egy biztosító agilisabban tud működni, ezáltal gyorsabban kiszolgálni ügyfeleit, és jelentősen csökkenteni az új termékek megalkotásának és piacra vitelének idejét, akkor olyan képességre tesz szert, amellyel dinamikusan tud reagálni a piac változásaira.

Az agilitás még olyan tradicionális iparágban is ért el sikereket, mint a fegyveripar, autóipar vagy a bankszektor (Saab, Barclays). Ezen példákból kiindulva hisszük, hogy a versenyszférában működő legtöbb cégben szükséges elindítani agilis projekteket, ezzel elindulva az agilitás útján.

Ez az egyik első lépés, hogy elkezdjük megtalálni azt, hogy nekünk mit és legfóképpen hogyan érdemes implementálni az agilis menedzsment tudástárából, ugyanis valószínűleg a válasz nem az, hogy mindent és azonnal. Meg kell találni azt a „hibrid” működési formát, amelyben a mi konkrét cégünk és annak kultúrája agilisabban, az ügyfeleinknek több értéket adva, ugyanakkor zökkenőmentesen és nem túl sokat kockáztatva tud működni.

Összegezve tehát: a szervezeteknek és legföképpen a cégek vezetőinek véleményünk szerint az agilis szemléletmódot (hogyan tekintenek a szervezetre, annak céljára és tagjaira) kell elöször elsajátítaniuk, ugyanakkor párhuzamosan a cégen belül projekteket indítani az agilitásnak a cikkben bemutatott minden halmazában, hiszen ezek egymást erösítve fogják kifejteni hatásukat, és teszik egyre inkább agilissá a teljes szervezetet.

\section{HIVATKOZÁSOK}

'Amazon, Apple, Google, Facebook, Microsoft 22001-ben kiadott „Manifesto for software development” kiáltvány, amelyet az agilis mozgalom hivatalos „nyitó" dokumentumanak tekintunk. (Beck et. al., 200)

Á gilis medzmivel

\section{IRODALOMJEGYZÉK}

Alexander Maasik (2018): Step by Step Guide to OKRs: Goal setting templates and examples, Weekdone Ltt.

rance-2019// Letöltés: 2020.10.06

Capgemini, Efma (2019) World Insurance Report 2019

Online. hit ps./// worldinsurancereport.com/resources/

Capgemini, Efma (2020) World Insurance Report 2020

Cathy B. Sarkar - Marco Locatelli (2017) A strategic integration between Agile and traditional project management approaches for a clear view on Project Closure in the Insurance industry: The Intesa Sanpaolo Life's case study. Umeå School of Business and Economics Csíkszentmihályi Mihály (1990): Flow: The Psychology of Optimal Experience, Harper and Row Publisher Inc.
Daniel Brosseau - Sherina Ebrahim - Christopher Handscomb - Shail Thaker (2019): The journey to an agile organization, McKinsey Online: https://www.mckinsey.com/business-functions/organization/our-insights/the-journey-to-an-agile-organization?cid=eml-app Letöltés: 2020.10.06.

nVG

- Mattias Skarin (2010): Kanban és Scrum: mindkettóböl a legiobbat, C4Media Inc

Online: https://rework.withgoogle.com/blog/tive-keys-to-a swcer

Ken Schwaber - Jeff Sutherland (2017): A Scrum Utmutato

The Agile Manifesto. Agile Alliance

Nemzeti Fejlesztési Miniszzérium (2017): Második Nemzeti Éghajlatváltozási Stratég

Online: https://www.kormany.hu/download///6a/f0000/N\%C3\%89S_2_strat\%C3\%A9gia_2017_02_27.pdf Letöltés: 2020.10.06. Pandurics Anett - Szalai Péter - Tóth Krisztián (2016): A klímaváltozás hatásai a magyar biztosittási piacra, Biztositás és Kockázat, vol. 3(4), pp. 38-61

https://doi.org/10.18530/bk.2016.4.38 Letöltés: 2020.10.06

Peter M. Senge (1990): The Fifth Discipline: The Art and
ProMan Consulting (2019): A Sprint Terveźs 8 lépése

Online: https://promanconsulting.hu/a-sprint-tervezes-8-lepese/ Letöltés: 2020.10.06

ProMan Consulting (2020) Kanban: Jelentése, elönyök/hátrányok, Kanban vs. Scr

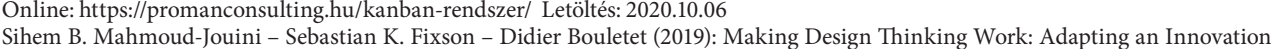
Approach to Fit a Large Technology-Driven Firm. Research Technology Management, vol 62 (5), pp. 50-58.

https://doi.org/10.1080/08956308.2019.1638485 Letöltés: 2020.10.06

Simon Hayward (2015): Connected leadership, Financial Times, Prentice Hall

Simon Hayward (2018): The Agile Leader, Kogan Page Limited

Online: https./Www: Stephen Denning (2018): The age of agile. how smart companies are transforming the way work gets done AMACOM

Talanx Best Practice Lab (2020): Ecosystem \& Platform Fundamentals Bootcamp konferencia anyage

Tatjana Bender - Karolien Gielen - Teresa Schreiber et al (2020): Digital Underinvestment Hurts Insurers. Boston Consulting Group Online: https://www.bcg.com/industries/insurance/digital-underinvestment-hurts-insurers.aspx?utm_medium=Email\&utm_ 